\title{
One God Or One Lord? Deuteronomi And The Meaning Of Monotheism
}

Natan Mac Donald, Tubingen: Mohr Siebech, 2012. 271 halaman.

ISBN: 316151680X, 978-316-15168-01

Reviewed by Marthin Steven Lumingkewas ${ }^{1}$

${ }^{1)}$ Dosen Sekolah Tinggi Teologi Tawangmangu

\begin{abstract}
Abstrak
Buku ini berupaya memahami ide monoteisme dan siknifikansi Yahweh dalam Ulangan, serta hubungan keduanya melalui beberapa teks yang terekam dalam Perjanjian Lama. Substansi dari penelitian ini adalah eksegesis mendalam beberapa pasal dalam Ulangan yang berhubungan dengan kesatuan Yahweh. Dimana ide utama yang dipaparkan sebagai 'Yahweh adalah satu' merupakan tema utama yang berkaitan dengan kesatuan Yahweh, keunikan Yahweh, keberadaan allah lain, arti mengasihi Yahweh, pemilihan Israel dan larangan penyembahan berhala melalui analisis literari-sejarah serta disimpulkan bahwa ide monoteisme modern tidak mampu mewakili model agama Israel yang menetapkan Yahweh sebagai allah 'unik' di antara allah lain.
\end{abstract}

\section{Pendahuluan}

Gagasan dan pentingnya ide 'kesatuan YAHWEH' (monoteisme dalam terma modern) telah menjadi perdebatan panjang dari para ahli teks Timur Dekat Kuno; khususnya teks Perjanjian Lama. Tidak berlebihan apabila ide dan konsep Allah Israel merupakan satu dari sekian banyak topik yang selalu dibicarakan; yang kemudian berkembang dalam beragam hasil tafsiran; termasuk di dalamnya pembahasan mengenai asal muasal dan natur dari iman monoteistik Israel.

Para pengikut William Foxwell Albright (School of Albright) sebagai contoh, percaya bahwa kitab Ibrani mengandung cukup banyak puisi menarik yang lahir pada sekitar akhir millennium kedua yang merefleksikan elemen-elemen penting tentang hadirnya monoteisme Yahwistik. Bagi 
Albright dan para pengikutnya, monoteisme telah lama lahir di Israel sebagai suatu hasil proses gradual dari politeisme menuju monoteisme. Penyembahan terhadap allah lain selain Yahweh hanya dianggap sebagai deviasi dari norma-norma yang telah dibuat.

Keberatan terhadap tesis Albright dan para pengikutnya kemudian bermunculan; diantaranya dimotori oleh Kuenen, Welhaussen dan B. Lang khususnya Lang yang menyatakan agama Israel awal yang kita kenal pada umumnya berasal dari konteks polemik biblikal melawan politeisme yang terekam dalam teks Ibrani. Yahweh adalah dewa nasional, tetapi bukan satusatunya dewa yang disembah. Bagi kelompok ini, ide eksklusivisme Yahweh hanya muncul dari para nabi abad ke 8 SM yang dimotori oleh Hosea melalui pergerakan kaum minoritas dengan ide "for Yahweh alone". Lang dan para pengikutnya percaya, merupakan kebodohan besar mengabaikan hasil mengesankan dari kritik sastra dan kritik sejarah. Dalam banyak kasus, kedua pendekatan kritik tersebut bersandar pada bukti yang dikumpulkan dengan susah payah, tak terbantahkan dan sangat diperlukan untuk pemahaman yang benar dari Perjanjian Lama itu sendiri. Hal pro dan kontra seperti ini yang mendorong paradigma penelitian monoteisme Israel terus terbuka dan tetap menarik sampai saat ini.

Berlandaskan perdebatan yang masih berkepanjangan ini, Mac Donald memberikan perspektif berbeda mengenai bagaimana memahami Allah Israel; khusunya ide monoteisme dengan menginterpretasikan rangkaian teks dari kaum Deuteronomis yang dianggap menelurkan ide 'kesatuan Allah' dalam kerangka berpikir sentralisasi ibadah Israel pada era sebelum pembuangan. Memang telah hadir berbagai tulisan mengenai Allah Israel dan monoteisme yang telah dihasilkan sejak empat dekade terakhir. Namun demikian - terutama karya yang dihasilkan dua dekade terakhir terlihat semakin maksimalis ataupun minimalis yang justru menimbulkan serangkaian pertanyaan yang semakin tidak mudah mendapatkan jawabannya.

Buku ini mencoba menjelaskan bahwa doktrin mengenai monoteisme yang terminologinya hadir pada era modern ini tidak akan mampu untuk menjelaskan doktrin mengenai sistem agama Israel atau doktrin mengenai Allah Israel yang terekam dalam teks-teks Deuteronomi, dikarenakan ide monoteisme modern pada dirinya sendiri memiliki defisit makna jika 
dipergunakan untuk menggambarkan atau menjelaskan komplikasi sistem agama Israel itu sendiri. Dengan mempergunakan beberapa teks dalam kitab Ulangan; seperti Ulangan pasal 4 dan pasal 6, Mac Donald percaya teks-teks tersebut merupakan afirmasi Deuteronomis bahwa Yahweh adalah Allah Israel sekaligus unik yang terefleksi dalam dua kata ha Elohim. Pernyataan yang tedapat dalam shema, perintah pertama dan Ulangan 4:35, 39 samasama memiliki klaim penolakan akan ilah lain dalam kehidupan Israel, sebab Yahweh adalah unik. Siknifikansi shema ini secara nyata terindikasi dalam struktur Deuteronomi dimana muncul panggilan empatik bagi devosi sepenuh hati Israel, wajib ingat pemilihan Allah, serta tidak memberikan ruang bagi allah lain berdiri menentang atau melampaui Yahweh. Yahweh adalah satu, Yahweh satu-satunya Allah Israel, tidak ada lainnyakorelasinya terdapat dalam perintah pertama.

Buku ini menjadi penting bagi para dosen atau mahasiswa yang bergelut dalam bidang ilmu teologi Perjanjian Lama atau biblika Perjanjian Lama; khususnya mereka yang berkonsentrasi dalam sistem agama Israel yang mana di dalamnya termasuk argumentasi mengenai monoteisme Israel. Buku ini sanggup membuktikan bahwa monoteisme yang dipikirkan orang modern bukan merupakan ide yang dimiliki oleh masyarakat Israel kuno yang terbiasa dengan pluralitas allah yang mereka sembah. Yahweh digambarkan menjadi 'salah satu' allah dari sekian banyak allah yang disembah-yang tergambar jelas saat raja Yosia melakukan reformasi di bait allah Yerusalem dimana Yahweh bersanding dengan Asherah dan ilah lainnya dalam bait allah tersebut. Dengan ini Mac Donald percaya bahwa terma monoteisme modern pada akhirnya tidak mampu menjelaskan ide 'kesatuan allah' (monoteisme?) yang terekam dalam Deuteronomi.

Pada bagian pertama, Mac Donald membahas terma 'monoteisme' sebagai terma yang pertama kali dimunculkan oleh Henry More (16141687) saat diskusi 'Panteisme' dalam presentasi berjudul The Grand Mystery of Godliness tahun 1660. Bagi More, Ateis yang menekankan pada 'meterialisme' merupakan musuh yang harus diperangi dan bukan politeisme itu sendiri - politeisme dalam arti percaya akan banyak allah bukanlah target More. Musuh sesungguhnya 'monoteisme' More adalah 'ateisme'. Musuh More bukanlah agama Yunani yang dianggap sebagai musuh ajaran Kristen, melainkan doktrin materialisme yang melekat pada 
faham Ateisme, yang membuat banyak orang percaya tersesat dengan pemikiran spekulatif mereka (bukan karena moralnya rusak atau mengabaikan Firman). Dengan ini kita dapat melihat bahwa ide monoteisme merupakan klasifikasi refleksi dari dasar agama-agama, dan bukan berasal dari perspektif dalam kekristenan - selain berasal dari ide era awal pencerahan.

Di tangan kaum empirisisme, istilah 'monoteisme' menjadi prinsip utama dari ide 'teisme', bahkan menjadi doktrin atau prinsip dari Unitarian. Mereka percaya bahwa agama pertama Musa sama dengan agama Akhenaton Mesir (Freud, Assman) berdasarkan teks Kisah Rasul 7: 'Musa diajar dengan semua kebijaksanaan Mesir'. Bagi mereka Musa merupakan Imam Mesir yang mendapat pencerahan yang kemudian dibuang keluar Mesir. Monoteisme Akhenaton Musa ini berbeda dengan agama Mesir. Menurut Freud terdapat hanya satu Allah, dan satu Allah ini tidak dapat direpresentasi oleh figur apapun. Mistis, ritual dan hal-hal superstisi tidak diijinkan. Tidak ada konsep setelah kehidupan, tidak ada allah perempuan dan allah bersifat universalistik. Musa Mesir yang monoteis tidak bisa diikuti oleh orang Yahudi, ia dibunuh dan kemudian digantikan oeh Musa Midian yang menyembah Yahweh; allah gunung. Agama Athen ditekan, dan dalam kacamata Freud, sejarah Yahudi menjadi sejarah 'kemuculan kembali' yang direpresi, yaitu agama Akhenaton dan agama Musa. Disinilah monoteisme Musa terkontaminasi. Mac Donald menyimpulkan monoteisme Freud ini bukanlah agama Israel yang tercetak dalam dokumen Amarna, ${ }^{1}$ melainkan model monoteisme yang merupakan konstruksi filosofis dari para pemikir abad pencerahan yang menentang segala bentuk superstisi.

Setelah membahas monoteisme yang lahir dari kaum Platonis Cambridge dan dari para pemikir era pencerahan, Mac Donald membawa pembahasan monoteisme pada studi Perjanjian Lama dunia modern dengan ide 'monoteisme' yang dipergunakan - sekaligus menganalis karya dari beberapa ahli yang membahas 'monoteisme'; dengan kelompok pertama seperti Abraham Kuenen dan Jullius Welhaussen, dan kelompok kedua diwakili oleh: W.F. Albright dan Y. Kaufman yang bertitik tolak dari penemuan Kuntillet 'Ajrud, dimana Kuenen dan Wellhausen memahami

${ }^{1}$ Assman J, Moses the Egyptian: The Memory of Egypt in Western Monotheism, (Cambridge, MA: Harvard University Press, 1997), hlm. 158. 
monoteisme dalam hubungannya dengan etika dan konsep universal Allah yang dapat dilacak kembali pada era Musa ketika ia - mengikat seluruh Israel dalam penyembahan kepada Yahweh yang dikunci dalam formulasi sepuluh hukum. Disinilah etika monoteisme dibangun serta menjadi senjata atau kekuatan motivasi Israel. Monoteisme yang dibangun ini bersifat gradual; berasal dari monolatri yang pada akhirnya berakhir pada absolut monoteisme. Dengan ini Yahweh menjadi 'spiritual' berbeda dari faham Platonis dan Materialisme terdahulu; Spirit dikatakan berbeda dari materi, yang pada akhirnya melahirkan pemikiran profetik terhadap deisme, kepada pemisahan Allah dengan alam, dan antara Allah dengan manusia. Yahweh menjadi satu-satunya Allah; sekaligus Allah perang dan keadilan yang partikularistik (monoteisme-partikularistik). Konsep ini menurut Wellhausen bertahan sampai pasca pembuangan; terutama tertanam dan terlihat dari para nabi-nabi Perjanjian Lama.

Hegemony monoteisme Kuenen dan Wellhausen berakhir ketika W.F. Albright dan Y. Kauffmann mematahkan teori Wellhausen ini sekitar era perang dunia kedua. Albright dalam bukunya From The Stone Age to Christianity: Monotheism and Historic Process yang diterbitkan tahun 1940 menjadi tolak ukur bagi era penafsiran teks-teks Ibrani yang mengandalkan penemuan Arkeologi sebagai alat tafsir utama. Berbeda dengan Kuenen dan Wellhausen, Albright melihat para nabi bukan sebagai penemu 'monoteisme etikal', melainkan pihak yang menginterpretasi pesan Musa. Mereka harus dipuji sebagai yang menemukan segala implikasi dari ide monoteisme. Sehigga penolakan ilah lain dalam Deutero-Yesaya misalnya, harus dilihat bukan sebagai perubahan teologis, namun refleksi pergerakan dari logika empiris menuju rasional-filosofis yang sistemik. Karya Albright selain menimbulkan pertanyaan mengenai perkembangan sejarah agama, juga membawa isu diskusi monoteisme Israel yang tidak terelakkan. Albright yang menawarkan definisi penuh atas ide 'monoteisme' (walaupun ia gagal menunjukkan bahwa Musa hanya percaya satu Allah saja) telah memperlihatkan kepada kita bahwa deskripsi monoteisme tidak pernah bersifat statis dengan hanya percaya akan satu allah saja.

Bagi Yehezkiel Kauffmann, istilah 'monoteisme' sebagai kontras atas politeisme, lebih berbicara soal 'sovereignty' daripada kesatuan aritmatika. Yahweh benar-benar berkuasa, dalam hal ini dia saja yang jadi Allah. 
Alkitab tidak memiliki teogoni mistis. Kaufman membuat perbedaan tajam antara 'bentuk' teks-teks biblikal dengan 'realitas' yang mendasarinya. Contohnya fragmen mistis yang ditemukan dalam kitab Ibrani dapat disingkirkan oleh penafsir yang mampu membuat artikulasi atau perbedaan antara Israel dan agama berhala dalam 'formulasi dokmatis'. Contoh praktis lain Kauffman adalah: gambaran Yahweh bergumul dengan monstermonster dalam teks Ibrani bukanlah pertempuran Yahweh dengan kekuatan terbesar, melainkan Yahweh sedang mengalahkan para makhluk yang memberontak tersebut. Realitasi ini menggambarkan kedaulatan dan kemahakuasaan Yahweh, sang pencipta satu-satunya; yang dalam 'bentuk' khusus - dimana teks biblikal terekspresi dalam penggunaan elemen-elemen mistis. Perbedaan 'bentuk' dan 'realitas' yang dipergunakan Kauffmann menciptakan efek kuat dalam analisis biblikalnya; kitab Ibrani walaupun terlihat saling bertentangan sistem kepercayaannya, pada hakikatnya bernuansa 'monoteisme'. Israel memiliki sistem 'monoteisme populer' yang dituntun oleh insting dan intuisi dan bukan spekulasi dan formulasi sistematis. Untuk itu, gambaran penyembahan berhala dalam teks Alkitab diterjemahkan semata hanyalah 'skill' manusia yang mengalami degenerasi Allah dan pada akhirnya mereka mendapat hukuman karena bergantung pada kemampuan dirinya.

Penemuan inskripsi di Khirbet el-Qom dan Kuntillet 'Ajrud yang menggambarkan kesatuan Yahweh dan Asherah, telah menciptakan pemandangan bertolak belakang antara kaum positivisme Albright dan Baltimore School dengan para sejarawan dan arkeolog modern yang melihat catatan pra-pembuangan Israel dengan nada skeptis. Muncul tendensi para ahli menempatkan catatan-catatan biblikal sebagai produk periode akhir pembuangan; ikonografi lebih utama daripada inskripsi; serta aspek interdisiplin ilmu menjadi pendekatan wajib dalam eksegese yang pada akhirnya menimbulkan pertanyaan-pertanyaan baru pada teks 'monoteisme'. PraIsrael dilihat sebagai Henoteistik (juga politeistik), sedangkan monoteisme sejati merupakan hasil periode pembuangan, yang pada akhirnya para ahli modern tersebut 'sungkan' untuk menggeneralisasi istilah monoteisme seperti pernah terjadi pada era Albright. Mac Donald memasukkan nama Robert Karl Gnuse dan Walter Dietrich Sebagai pelopor era ini. Gnuse dengan bukunya No Other Gods: Emergent Monotheism in Israel yang 
terbit tahun 1997, menggunakan metode 'punctuated equilibria' sebagai model pendekatan biologis ke dalam ilmu social; dalam hal ini dalam upaya menafsir teks-teks Ibrani. Para ahli modern yang menggunakan pendekatan Gnuse menggunakan istilah 'gradual development' terhadap monoteisme sebagai perlawanan monoteisme 'revolusi' Albright. Punctuated Equilibria menempatkan identitas Israel dan sistem keagamaanya terlihat mengalami evolusi; suatu evolusi dalam lompatan quantum dalam respon terhadap perubahan/keadaan sosial tertentu atau krisis keagamaan. Bagi Gnuse, punctuated equilibria menggambarkan teori mengenai 'monoteisme' yang berkembang melalui serangkaian pergumulan periode sebelum pembuangan dan akhirnya muncul pada era pembuangan. Menurut Mac Donald, Gnuse memproduksi 6 karakteristik monoteisme yang digolongkan sebagai berikut: pertama, Alkitab mengembangkan gambaran aktivitas Allah dalam sejarah. Kedua, Yahweh tidak pernah terikat dengan natur alam semesta ini. Ketiga, etika menjadi faktor dominan yang berbeda dengan dunia sekitar Israel. Empat, kebebasan manusia mendapat tempat lebih besar dalam Israel. Lima, keadilan sosial dan egalitarian menjadi praktis dan bukan sebatas retorika para penguasa. Keenam, universalisme 'dari atas' dunia sekitar Israel dilawankan dengan universalisme 'dari bawah'; yaitu universalisme Yahweh, melalui proklamasi keadilan dan keselamatan. Universalisme ini menurut Gnuse akan menuju kepada misi Kristen di kemudian hari.

Bentuk monoteisme seperti ini bagi Mac Donald belum mewakili ide monoteisme dalam Perjanjian Lama. Wellhausen dan Kuenen bagi Mac Donald belum mencapai apa yang disebut kebenaran spiritual dan universalistis monoteisme. Albright dan Kauffman disatu pihak telah 'melebih-lebihkan' ide monoteisme bahkan melakukan 're-interpretasi' ketika bertemu teks yang berlawanan. Untuk itu, ia menawarkan satu bentuk pendekatan lain yaitu metode 'kanonikal' untuk menjawab problem monoteisme. Pertama-tama Mac Donald membahasa model 'biblikal alternatif monoteisme ala J. Sawyer yang terkenal dengan problematika natur teks biblikal itu sendiri. Bagi Sawyer, teks harus ditimbang secara aritmatika; dan sejak material monoteistik beratnya ringan (hanya $25 \mathrm{x}$ muncul), maka tidak harus menjadi bagian utama dalam teologi Kristen teks-teks monoteistik tidak pernah memainkan peran utama dalam Perjanjian Lama. ide Sawyer ini diikuti oleh Clement yang percaya bahwa 
kanon telah menempatkan teks non moneteistik ke dalam kerangka monoteistik berdasarkan kepercayaan akan satu Allah yang pada akhirnya menstimulus dibentuknya Kanon 'satu' Allah yang menuntut satu pewahyuan; sebaliknya, satu pewahyuan menuntut satu Allah. Identik dengan Sawyer, Clement yakin ide monoteisme merupakan warna tetap Perjanjian Lama.

Berlanjut pada Bab II, kita diajak Mac Donald menggunakan beberapa teks Ulangan untuk membahas ide monoteisme Israel, beberapa diantaranya adalah:

The Lord is God; there is no other besides him (Dt.4:35)

The Lord Is God in heaven above and on the earth beneath; there is no other (Dt. 4:39)

You Shall have no other gods before me Dtl.5:7)

Hear (shema) O Israel: The Lord Is Our God, The Lord Alone (Dt. $6: 4)$

The Lord Your God is God (Dt. 7:9)

The Lord your God is God of gods and the Lords of Lords, the great God, mighty and awesome (Dt.10:17)

See now that I, even I, am he; there is no god besides me (Dt. 32:29)

here is none like God, O Jeshurun (Dt. 33:26)

Seluruh teks di atas menurut Mac Donald merupakan afirmasi Deuteronomi terhadap Yahweh yang beroperasi dalam masing-masing konteksnya. Dari semua teks di atas, Mac Donald melihat Ulangan 6:4-9 yang memiliki istilah shema menunjukkan pernyataan mengenai kesatuan Yahweh (Yahweh oneness). Shema menurut Mac Donald memainkan peran penting dan utama dalam tradisi Yahudi dan Kristen. Yahudi menggunakan shema sebagai bagian pembuka dan pembukaan doa setiap hari. Bagi kekristenan, shema, diterima sebagai perintah terbesar. Dalam sejarah Perjanjian Lama, shema dipahami sebagai slogan reformasi Yosia. Shema selalu berada dibagian depan kehidupan Israel yang tidak ada paralel dibagian manapun teks Ibrani. Namun demikian, para ahli nampaknya mengalami kesulitan menterjemahkan istilah Yahweh Elohim Yahweh ehad. Menurut Mac Donald, persoalan terletak pada titik mengkombinasikan setiap kata-kata tersebut di atas. Empat pertanyaan sulit yang muncul adalah: pertama: dalam konteks apa seharusnya teks ini dibaca? Kedua, 
apakah kata kerjanya dalam bentuk tersamar, dan jika tidak, bagaimana kata kerja ini seharusnya dipahami? Ketiga? Manakah yang menjadi predikat dan mana yang menjadi subjek? Keempat, apakah arti 7 Trֶ?? Mac Donald melampirkan 4 tafsiran/terjemahan yang masih menyisahkan ruang argumentasi dari teks Ul. 6:4-9; khususnya terminologi אחד

1. YAHWEH is our God; YAHWEH is one;

2. YAHWEH, our God, YAHWEH is one;

3. YAHWEH, our God, is one YAHWEH;

4. YAHWEH is our God, YAHWEH alone.

Veijola dan Loretz menterjemahkan poin 1 sebagai 'you are my God' and 'I am your God'. yang pertama mengidentifikan Yahweh sebagai Allah Israel. Kalimat kedua menyatakan bahwa hanya Yahweh satu-satunya yang menjadi Allah Israel. Terjemahan poin 2 memahami kata kerja sebagai predikat bersama dengan אחד yang juga sebagai predikat. Translasi ini didukung oleh beberapa varian teks awal (Septuaginta, Vorlage dan Papirus Nash). Mac Donald mencatat ada 2 kelemahan dalam terjemahan ini: pertama, Yahweh kedua menjadi tidak efektif (baca: tidak berguna), kedua, hubungan subjek - predikat menjadi problematik dalam mengklasifikasi kalimat ini. Poin ketiga, Yahweh, our God, is one Yahweh, menurut Mac Donald menyelesaikan masalah Yahweh yang diulang haruslah dengan memahaminya sebagai kata predikat tunggal. Dengan "Yahweh Allah kita" sebagai subjek dan "Yahweh one" sebagai predikat. Bagi Mac Donald, kalimat ini menjadi slogan mono-Yahwism yang berfungsi sebagai pembeda dengan banyaknya tempat pemberian korban yang menjadi tempat penyembahan Yahweh dengan bentuk dan tradisi berbeda yang mana dalam pergerakan Deuteronomis dinyatakan sebagai hanya satu Yahwweh yang harus disembah dalam satu tampat ibadah.

Sedangkan kalimat dalam poin ke 4, Yahweh is our God, Yahwewh alone, yang diterjemahkan sebagai "Allah kita adalah Yahweh, Yahweh saja”, dipandang Mac Donald bermasalah dengan tiga alasan: Pertama, tidak konsisten dengan penggunaan Yahweh dan Eloheinu dalam Deuteronomi. Kedua, istilah אָָ yang berdiri dengan kalimat ini tidak dipahami berfungsi sebagai kata sifat. Ketiga, harus ditetapkan apakah אחָ bisa berfungsi sebagai kata sifat jika dipasangkan dengan kata "alone". Bagi Mac Donald, Ulangan 6:4b harus dibaca dalam konteks Deuteronomi dan 
dipahami sebagai "a single predication, with $7{ }_{\tau}$ " as the predicate", sehingga menjadi 'Yahweh, our God, is one Yahweh, yang pada akhirnya menjadikan Ulangan 6:4 sebagai pernyataan mono-Yahwisme yang tentu saja berlawanan dengan keberadaan poly-Yahwisme di Israel sebagai respond Deuteronomi terhadap apa yang dinamakan inskripsi Kutillet 'Ajrud yang memiliki referensi 'Yahweh dari Teman' dan 'Yahweh dari Samaria'.

Mono-Yahwisme yang tetap menyediakan ruang bagi keberadaan allah lain di Israel (in se, menggambarkan kenyataan kehadiran allah lain tidak mungkin dihilangkan dalam catatan Ibrani) dimaksudkan oleh Deuteronomi sebagai upaya untuk memanggil kembali Israel kepada pengakuan bahwa Yahweh adalah unik di Israel, dan mereka harus menerima serta menyembahNya dengan sepenuh hati. Hal ini pada akhirnya berhubungan dengan perintah pertama Dekalog; dimana kalimat 'al panay' yang dalam terjemahan mayoritas teks Jerman menjadi "di sebelah aku"; paralel dengan U1. 32:39 'there is no God with me'. Pengertian kedua atas teks ini 'diseberang aku, didepan wajahku' - perintah yang melarang meletakkan berhala apapun di hadapan Yahweh. Namun bagi Mac Donal, terjemahan di atas bermasalah mengingat istilah 'al panay' lebih mendekati pada 'on the surface of' (Kej. 1:2) yang sering muncul dalam ekspresi "bersujud di depan seseorang". Untuk itu Mac Donald mengusulkan penggunaan 'al panay' dimanapun dalam Perjanjian Lama Seharusnya berbunyi "You shall have no other gods over and against me'. Allah lain adalah ancaman pada Yahweh dan mengikuti mereka merupakan tindakan pembangkangan. Shema dan Perintah Pertama mengklaim bahwa hanya Yahweh satu-satunya allah Israel. Bangsa lain juga memiliki allah, namun menyembah mereka dilarang. Dalam rancang pembicaraan para ahli modern, kepercayaan ini disebut monolatri. Namun dalam pembacaan awal Deuteronomi, dimana shema dan perintah pertama ditemukan, merupakan panggilan untuk menyembah Yahweh saja - jika teks ini dibaca dalam pemikiran monoteistik (UL.6:4) yang merupakan karya editorial yang telah menjadikan 'kesatuan Yahweh (Yahweh oneness) sebagai tema sentral Deuteronomi yang dimulai dari pembacaan Ulangan 4:35, 39 ketika 
Yahweh dinyatakan sebagai satu-satunya Allah. Keduan teks ini menurut para ahli modern merupakan ekspresi nyata ide 'monoteisme'. ${ }^{2}$

Mac Donal melihat Ulangan 4:35, 39 merupakan afirmasi Yahweh adalah Allah Israel, yang sekaligus unik dan terefleksi dalam kalimat $h a$ Elohim. Pernyataan dalam shema, perintah pertama dan Ulangan 4:35, 39 sama-sama memiliki klaim penolakan akan ilah lain dalam kehidupan Israel, sebab Yahwe adalah unik. Ulangan 4 merupakan kulminasi dari argumentasi pengalaman Israel di Mesir dan Sinai, dimana Israel dipanggil untuk mengenal dan mengakui keunikan Yahweh yang menjadi Allah mereka satu-satunya dengan konsekuensi menolak ilah lain seperti yang terlihat dalam perintah Pertama, yang terefleksi dengan munculnya 'larangan keras' menyembah allah lain. Pada akhirnya dalam shema, Yahweh adalah unik bagi Israel sebagai dasar penyembahan sepenuh hati kepada Allah (Ul. 6:5) yang kemudian menjadi tema Ulangan 6-11. Siknifikansi shema (Ul. 6:4-9) pada akhirnya nyata diindikasikan dengan ditempatkannya dalam struktur Deuteronomi serta panggilan empatik bagi devosi sepenuh hati Israel. Yahweh adalah satu, Yahweh satu-satunya Allah Israel, tidak ada lainnya - yang instruksinya terdapat dalam perintah pertama.

Bagian ketiga dari buku ini membahas mengenai bagaimana Israel mengekspresikan kasihnya kepada Yahweh yang merupakan bagian dari afirmasi 'Yahweh adalah satu', dilakukan dalam 3 cara. Pertama, metafora 'kasih' dieksplorasi dalam 3 konteks berbeda yang diusulkan Deuternomi: perkawinan, filial, dan politik. Kedua, mengkaji penggunaan Deuteronomi tentang mengkaji istilah herem dalam Ulangan 7.

Mac Donald melihat Deuteronomi terkesan tidak membuat pernyataan eksplisit penggunaan istilah 'perkawinan' dimana istilah 'kasih/ahava' dipergunakan untuk mendeskripsikan hubungan Israel dengan Yahweh seperti yang digambarkan Yeremia dan Kidung Agung. Sebaliknya, gambaran 'parental' yang ditemukan dalam beberapa catatan Deuteronomi dipergunakan untuk mengekspresikan hubungan antara Yahweh dengan Israel. Perintah untuk mengasihi, diekspresikan dalam ketaatan terhadap seluruh perintah sebagai sarana Yahweh menguji Israel sekaligus sebagai tindakan untuk merefleksikan disiplin pada anaknya supaya tercipta kesatuan antara tindakan dan maksud yang dikandang dalam istilah ahava

${ }^{2}$ Dalam daftar BHS tidak terdapat variasi tekstual yang siknifikan 
itu sendiri, seperti penggunaan istilah ahava yang dibuat dalam kerangka perjanjian politik atau sumpah kerajaan. Ahava dipergunakan sebagai terminologi diplomatik untuk menunjukkan loyalitas yang ditunjukkan oleh anak buah kepada tuannya atau daerah jajahan kepada penjajahnya. Ekspresi lain dalam upaya mengasihi Allah yang ditemukan Mac Donal diperoleh dalam terminology ירא (takut), yang ditujukan kepada YAHWEH dan bukan kepada allah Kanaan. Takut kepada Allah yang bukan objek teror, melainkan dilakukan dalam ketaatan akan perintah-perintahnya.

Akan tetapi, Mac Donald melihat ada yang mengganggu dalam artikulasi mengenai natur mengasihi Yahweh yang terdapat pada terminology herem, yang merupakan legislasi Ulangan 7; yang secara struktural argumennya mirip dengan shema (Ul.6:10-25). Istilah ini dipergunakan pertama-tama sebagai bentuk larangan anak-anak Israel kawin dengan bangsa Kanaan. Kedua, perintah untuk menghancurkan semua bentuk penyembahan Kanaan yang dapat menjauhkan Israel dari kasihnya kepada Yahweh. Hal ini terekam dalam Ulangan 7:2 "jangan mengadakan ikatan perjanjian dengan mereka sekaligus dilarang mengasihi mereka." Kalimat ini nampaknya menjadi bentuk pernyataan negatif dari herem. Istilah herem mengindikasikan devosi kepada Yahweh sebagai tindakan ketaatan radikal, ${ }^{3}$ suatu tindakan ketaatan yang mungkin saja bertabrakan dengan dorongan natural manusia/ alam; dalam hal membasmi orang Kanaan, herem merupakan indikasi evokatif natural. Bahkan jika ada imam Israel, anggota keluarga, atau seluruh Israel terlibat dalam penyembahan berhala, maka semua ini akan menjadi objek herem. Mac Donald melihat aplikasi herem terhadap kota Israel yang meninggalkanYahweh lebih keras daripada kota-kota Kanaan.

Mac Donald melihat ada hubungan penting antara mengasihi Allah dan menjalankan herem yang muncul dalam teks 2 Raja-Raja 23. Loyal dan mengasih Yahweh dalam Ulangan 7 dan 2 Raja-Raja 23 diekspresikan dalam penghancuran tempat penyembahan kepada allah selain Yahweh. Tindakan ini menurut Mac Donald mendapat pembenaran dalam status Israel sebagai bangsa yang kudus (Ul.7:6). Mengutip dari Gammie dan Wells, diperoleh fakta bahwa kekudusan Israel tidak didirikan atas prinsip

\footnotetext{
${ }^{3}$ Yang bisa ditunjukkan dengan menyapu bersih semua bangsa Kanaan atas perintah Yahweh sebagai aksi nyata ‘kasih' kepada YAHWEH.
} 
imitation dei, walaupun Deuteronomi mengenal istilah ini (10:18-19). Melainkan, berasal dari ide 'kesatuan Allah dan pemilihan ilahi atas Israel'. Konsep kekudusan Deuteronomi adalah mengenai pemisahan Israel dengan

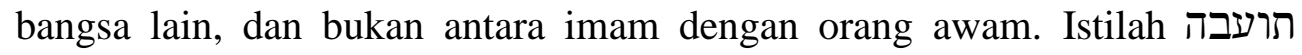
'kejijikan' Kanaan memberikan legislasi pada Israel untuk menghindar atau menghacurkannya. Sehingga konsep herem menjadi kendaraan ideal dalam mengeskpresikan response Israel terhadap objek dan praktek penyembahan asing di Kanaan; praktek yang harus dihancurkan. Namun Mac Donald tidak menyarankan istilah herem dipergunakan dalam pengertian perintah untuk membasmi Kanaan. Sebab memahami herem sebagai penghukum sangat problematik. Penggunaan istilah ini lebih kepada pengertian 'ancaman Israel terkontaminasi', dan bukan sebagai tindakan penghukuman, seperti yang terlihat pada cerita Akhan dalam Ulangan 13 yang lebih menekankan aspek kontaminasi daripada menjatuhkan penghukuman. Atau peristiwa penghancuran wiayah Transjordan sebagai refleksi ketaatan kepada perintah Yahweh, daripada ide menerima herem dalam kerangka raja Sihon dan Og layak menerima penghukuman karena mengeraraskan hati.

Konsep modern membaca monoteisme sebagai pengakuan intelektual, dimana hanya hadir satu Allah, dan tidak ada allah lain. Bagi Deuteronomi, respon tepat kepada kesatuan Yahweh adalah dengan segenap hati mengasihi dan memberikan devosi kepadanya. Mengasihi Allah diekspresikan dalam suatu tindakan konkret, partikular, sebagai kontras terhadap pemikiran intelektual modern mengenai monoteisme (yang juga dipercaya oleh Rabinik). Jadi istilah monoteisme dalam hubungannya dengan mengasihi Allah adalah Israel harus memiliki dan memberikan korban persembahan yang berbeda dengan orang Kanaan. Bukan hanya itu saja, mereka juga harus menghancurkan tempat dan berhala Kanaan serta dilarang kawin campur. Inilah monoteisme Israel.

Pada bagian ke empat, Mac Donal melihat pentingnya mengutip dua ayat pertama shema yang diikuti oleh enan instruksi yang menggarisbawahi pentingnya pengakuan terhadap 'kesatuan Yahweh dan perintah untuk mengasihiNya dengan segenap hati; sekaligus mengindikasikan respon yang diminta Yahweh yang harus terus menerus siaga (UL. 6:6-9). Instruksi ini sebagai berikut: (6) they are to be upon your heart; (7) Repeat them to your sons (7); Recite them when you rest at home, when you walk, when you lie 
down and when you rise (7); Bind them as a sign on your hand (8); they are to be as a frontlet between your eyes (8); write them upon the doorposts of your house and on your gates (9). Objek dari setiap instruksi adalah "perkataan-perkataan tersebut di atas", namun untuk apa "perkataanperkataan ini" (הּדּבריים האלה) ditujukan? Menurut Mac Donald, jawabannya tidak tergantung pada arti "perkataan-perkataan ini” dan 'aku memerintahkan kepadamu hari ini' dalam Deuteronomi semata; namun juga harus bergantung pada cara dimana ke enam instruksi ini dimengerti.

Mac Donald menemukan ha devarim ha eleh dalam shema, lebih baik dipahami "perkataan-perkataanKu' daripada 'perkataan-perkataan ini', yang mana instruksi ini ditempatkan dalam hati (Ay.6), sebab hati merupakan kursi dari pikiran; sekaligus kursi memori. Dengan ini para ahli menafsirkan isntruksi ini sebagai 'yang harus diingat'. Cara bagaimana perkataanperkataan tersebut harus diingat digambarkan dalam ayat 7 .

Selanjutnya Israel harus 'mengajarkan berulang-ulang perintahperintah ini kepada anak-anaknya' (ay.7). Kalimat ini jelas memerintahkan untuk 'mengajar' supaya menjadi 'tajam'. Ketiga, kalimat 'membicarakan/menyatakan ketika duduk di rumah', dalam perjalanan, berbaring dan bangun (ay.7), memiliki arti menyatakan shema berulangulang di pagi dan malam hari tanpa henti. Instruksi ke lima dan enam dalam ayat 8 dan 9, menurut Mac Donald harus dipahami secara literal daripada metafora. Kalimat 'perintah-perintah ini' harus menempel di tangan dan dahi dimaksudkan agar supaya semua 'perintah' ini dapat terlihat. Akhirnya ha devarim ha eleh yang harus dituliskan pada tiang pintu rumah dan pada pintu gerbang mengandung arti segala kekudusan haruslah diteruskan kepada seluruh bangsa. Seluruh instruksi ini harus digenapi dalam cara tertentu; terutama bagaimana menerapkan semua perintah ini secara konstan kepada Israel dan keturunannya.

Tema 'memori' yang ditemukan dalam Deuteronomi berkaitan erat dengan 'melupakan' dan mengingat' sebagai upaya ekspresi kasih Israel kepada Allah. Israel harus ingat saat di padang gurun, ingat kepada Yahweh; mengikuti allah lain adalah melupakan Yahweh; sekaligus berhubungan dengan 'tanah' yang kelak diberikan. Ketaatan (baca mengingat) akan membawa kehidupan di tanah perjanjian. Hal ini wajib mereka lakukan dikarenakan pemberian tanah (nahalla) merupakan bagian dari ikatan 
perjanjian antara Yahweh dengan umatnya. Restrospeksi ini mengandaikan Israel yang masih di padang gurun, dimana mereka diuji, dibuat rendah hati dengan membuat mereka lapar; agar mereka sadar bahwa mereka tidak hidup dari roti saja. Manusia harusnya bersandar dan taat pada peraturan yahweh, bukan kepada roti, sekaligus hal ini membuat mereka mengenal Allah dengan benar. Israel harus terus mengingat Yahweh dan bukan melupakannya. Jika mereka melupakan Yahweh (bukan perintah atau fakta intelektual), mereka otomatis sudah tidak taat kepadanya. Tujuan dari formulasi moral telah hilang; kehilangan Yahweh merupakan pemberontakan terhadap mulut Yahweh; yaitu hukum-hukumnya.

Ulangan 8, menjelaskan 'makanan' yang menjadi alat pantau Deuteronomi dalam ekspresi Israel untuk saat mengingat Yahweh. Melalui kelaparan dan manna, bangsa ini mengekspresikan sikap rendah hati dan kebergatungannya kepada Yahweh. Dan melalui kelimpahan roti mereka mengekspresiskan rasa syukurnya. Mengingat Yahweh diekspresikan dalam beberapa cara konkret: melalui kerendahan hati, ucapan syukur dan ketaatan kepada perintah. Pada akhirnya kita melihat model monoteisme yang dianut Deuteronomi tidak mirip dengan monoteisme para Rabi Yahudi atau dalam terma modern. Bagi Deuteronomi, monoteisme tidak dikarakteristikkkan oleh stabilitas inheren, melainkan bergantung pada kehidupan Israel itu sendiri. Agar supaya tidak melupakan Yahweh, perintahNya haruslah dipelajari, dikumandangkan dan diajarkan, sebagai suatu bentuk proses disiplin. Disiplin ini akan membawa kepada pengenalan terhadap kebergantungan total Israel kepada Yahweh dan hukumhukummnya. Bagi Deuteronomi ini adalah pengakuan akan Yahweh sebagai satu-satunya Allah. Pengakuan bahwa tidak ada allah lain selain Yahwne, dimana hidup dan matinya Israel bergantung padaNya.

Pada bagian ke lima dari buku ini Mac Donald menekankan pentingnya konsep shema yang merupakan jalinan hubungan Israel dengan Yahweh yang dapat diukur dengan istilah bahar (pemilihan) - yang dalam Ulangan 7:6-8 sering digambarkan sebagai locus classicus dari pemilihan, yang juga merupakan warna unik Yahweh dengan istilah 'formula ikatan perjanjian'. Locus classicus bersama narasi Lembu Tuangan, intersesi Musa dalam Ulangan 9-10 dan 4, serta Nyanyian Musa, menurut Mac Donald merupakan pertimbangan dasar bagi konsep pemilihan Israel. Locus 
classicus pemilihan dalam Ulangan 7:6-8, muncul dalam konteks perintah dimana bangsa-bangsa Kanaan menjadi herem. Israel menjadi 'bangsa kudus'; dalam terma Deuteronomi 'harta, kepemilikan paling berharga', apabila ia mentaati semua perintah yang diberikan kepadanya di Sinai. Perihal kudus dan tidak kudus, antara yang diterima dan tidak diterima, merupakan simbolisasi perbatasan antara Israel dan bangsa lain sekitarnya. Semua ini merupakan indikasi keberbedaan Israel yang merupakan umat Yahweh. Gagal mengikuti perintah ini, akan membahayakan perbedaan antara penyembah Yahweh dengan penyembah ilah lain (Ul. 12:29-14:19).

Penggunaaan Deuteronomi atas istilah am qadosh, ternyata bukan semata soal pemisahan Israel dengan bangsa lain (7:6; 26:17-19), melainkan merupakan komitmen Israel kepada ikatan perjanjian itu sendiri dimana Yahweh menjadi Allah mereka dan mereka menjadi umatNya; Israel akan menjadi am seglah - harta berharga yang namanya diagungkan, dipuji dan dihormati. Menurut Mac Donald, hubungan antara staus am qadosh dan ketaatan kepada perintah diindikasikan oleh terminology dimana istilah ini menempatkan status am qadosh Israel tidak bergantung pada ketaatannya akan hukum Yahweh melainkan pada posisinya yang mengekor pada $h a$ devarim itu sendiri. Hal ini nampaknya terekspresi dalam teks 26:17-19 dimana bukan ketaatan dan penghormatan akan status am qadosh yang saling mendahului, melainkan hubungan antara satu dengan lainnya yang merupakan hak khusus serta nuansa tanggungjawabnya.

Israel dipilih dan dijadikan bangsa yang kudus dimana dasar pemilihan Israel ini nampaknya berdasarkan kasih Yahweh kepada bangsa ini dan janjinya kepada Patriak. Pemilihan Israel dalam Ulangan 7:9-10 dan 5:9-10 memiliki beberapa perbedaan. Pertama konsep berit yang tidak muncul dalam 5:9-10. Dalam konteks pasal 7, berit tidak dihubungkan dengan peristiwa Horeb atau perjanjian Moab, melainkan sumpah Yahweh kepada patriak (ay.8). Selain itu, Mac Donald menemukan bahwa berit mengalami pembalikan dalam dekalog dimana Dekalog lebih menekankan kemarahan Yahweh kepada mereka yang tidak menghormatinya. Dekalog lebih menekankan kepada konsekuensi yang muncul apabil menentang Yahweh.

Masih menurut Mac Donald, masing-masing pasal berbeda dalam menggambarkan ekspresi kemarahan Yahweh kepada mereka yang 
menentangnya. Dalam pasal 5:9 dosa para bapa jatuh kepada anak-anaknya, dan atas generasi ketiga dan keempat. Dalam pasal 7:10, Yahweh membalas kepada mereka yang menentangnya tepat dimukanya. Perbedaan terletak pada ide tanggung jawab bersama oleh penulis 7:10. Sehingga kita melihat dalam dekalog kemarahan ilahi berlaku pada generasi ketiga dan keempat, namun tidak menutup pintu kasihnya kepada ribuan. Sedangkan dalam Ulangan 7 Yahweh menunjukkan kasihnya kepada seribu generasinya; sekaligus menghukum mereka yang menentangnya. Inti dari kedua teks di atas adalah sekalipun Yahweh menunjukkan murkanya kepada mereka yang berbalik dariNya, namun kasih pemilihan dan kesetiaannya akan terus terjaga kepada Israel karena pemilihan Israel kepada para Patriak. Untuk itu, ketaatan Israel kepada Yahweh disatu sisi penting dijaga dan dijalankan, sekaligus Israel menyadari bahwa pemilihan Yahweh atas mereka yang berdasarkan kasihnya (7:8) tidak mungkin batal dan akan terus berlanjut kepada ribuan generasi setelah mereka. Pengakuan akan Yahweh sebagai Allah dan janji pemberian tanah mengalir dalam tindakan pemilihan Yahweh, yang didefinisikan dalam terma 'kesetiaan' Yahweh kepada Israel.

Monoteisme dan pemilihan Allah atas Israel juga nampak nyata dalam peristiwa lembu tuangan dan doa intersesi Musa dalam Ulangan 9-10. Menurut Mac Donald, peristiwa ini dibagi dalam dua bagian besar. Pertama, ditenggarai dengan pemberontakan Israel (ay.7-22) beserta lokasi dimana mereka melakukan pemberontakan (ay.8, 22-23). Bagian ini nampaknya menekankan kepada dosa besar Israel dan kemarahan Yahweh. Bagian kedua, 9:25-10:11, berkenaan dengan intersesi Musa dan keberlanjutan anugerah Yahweh kepada umat itu. Baik ayat 7:9-10 maupun 9:25-29 menunjukkan aspek pemilihan Allah atas Israel; terutama bagian terakhir yang berisi intersesi Musa; pertama, ia memohon kepada penebusan Yahweh, kedua, ia mengingatkan Yahweh akan janjinya kepada para Patriak. Implikasi dari peristiwa ini dan dalam konteks Deuteronomi adalah: Israel selalu menjadi pusaka khusus Yahweh. Dengan ini Mac Donald memperlihatkan kita bahwa natur dari level pemilihan Israel sangat paradox, sekaligus peristiwa di Horeb ini mengindikasikan bagaimana paradox ini dipahami. Ketaatan Israel merupakan suatu yang pasti, sekaligus pemberontakannya akan dihukum dengan segera. Berbarengan dengan itu, kesetiaan Yahweh kepada janjinya, serta ketidaktaatan Israel tidak akan 
membawa kepada pemutusan hubungan khusus dengan Yahweh. Inilah paradok doktrin pemilihan dalam peristiwa Horeb. Peristiwa Horeb dan keluarnya Israel dari Kanaan yang dilanjutkan dengan pendudukan Kanaan meminta adanya pengakuan akan Yahweh sebagai Allah. Pengakuan Yahweh sebagi Allah selalu bermula dari pemilihan Yahweh atas Israel. Nyanyian Musa dalam Ulangan 4, bagi Mac Donald merupakan drama pemilihan Israel yang ditandai dengan kalimat eksplisit Ulangan 4:37-38: "because he loved your fathers he chose his seed after him and he brought you out of Egypt by his presence, by his grace, by his strength..." Melalui teks ini kita melihat tindakan pemilihan Yahweh kepada Israel berdasarkan dua alasan: pertama, Israel dipilih karena janji dan kasihnya kepada para Patriak. Kedua, pemilihan Israel berhubungan erat dengan keluaran dari Mesir dan pemberian tanah perjanjian yang mana 'tindakan' pemilihan ini

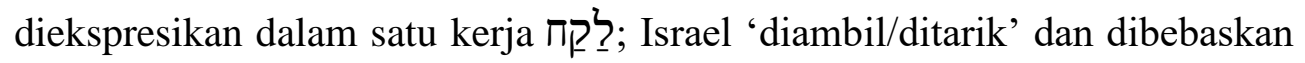
keluar dari Mesir untuk menjadi milikNya. Keunikan Yahweh yang dikenal dalam pemilihan dan penebusan atas Israel, yang menjadi tema sentral 4:3240 pada akhirnya menciptakan keunikan bagi Israel itu sendiri. Israel menjadi unik karena ia bergantung kepada Yahweh; dimana mentaati dan menerima hukum-YahwehEH, dan bukan karena pengenalan atau pengakuan dari Israel itu sendiri.

Yahweh direpresentasikan sebagai satu figur unik. Dia satu-satunya; dia Allah, atau Allah dari segala allah. Tidak ada yang sepertinya di Israel. Namun, keunikan Yahweh tidak dapat terlepas dari pemilihannya atas Israel. Bagi Deuteronomi tidak ada akses mengenal keunikan Yahweh terlepas dari hubungan dan pengenalan sejati kepada Yahweh yang dimiliki Israel sebagai hasil dari tindakan pemilihan atas bangsa ini. Hal ini menurut Mac Donald berlaku juga bagi bangsa-bangsa lain diluar Israel. Hubungan mereka dengan Yahweh tidak bisa terlepas dari Israel itu sendiri. Bagaimana bangsa-bangsa berespon terhadap Israel ditentukan oleh respon mereka kepada Yahweh. Inilah gambaran jelas dalam narasi nyanyian Musa ketika musuh Israel adalah musuh Yahweh juga.

Monoteisme dan Universalisme di Israel dan bangsa-bangsa sekitarnya pada akhirnya dapat dihubungkan dengan pemilihan Yahweh atas Israel yang dipresentasikan dalam horizon universal. Israel dipilih diantara bangsa-bangsa; untuk itu ia mendapat hak khusus diantara mereka. 
Pengetahuan dan pengenalan akan Yahweh diperoleh bangsa lain melalui Israel. Namun, Mac Donald juga mencatat bahwa hubungan antara pengakuan dan ketaatan Israel kepada perintah Yahweh menjadi problematik ketika bangsa ini tidak taat. Penghukuman Yahweh menjadi semacam ancaman pengenalan akan dia kepada bangsa-bangsa. Dilemma bagi Mac Donald dapat diselesaikan melalui langkah logic paradox pemilihan dimana Yahweh melakukan restorasi atas umatnya (Ul.9:25-29). Dalam pemilihan; kasih setia dan cemburu Allah muncul ketika mereka tidak taat. Berdasarkan formula ini, bangsa-bangsa akan mengenal sesuatu tentang Yahweh (23:43). Melalui tindakan ini Israel dapat melihat siapa Yahweh sesungguhnya. Bagi Deuteronomi, kesetiaan Yahweh yang lintas generasi berpadupadan dengan murkaNYa kepada mereka yang tidak taat. Disinilah ketaatan pada perjanjian dan kasih menjadi sesuatu yang harus dijaga karena akan selalu dilawankan dengan murka Allah walaupun konsep pemilihan tidak mungkin digagalkan.

Dalam bagian ke enam, Mac Donald membahas ide atau pemikiran monoteisme dengan penyembahan berhala yang kemudian menimbulkan pertanyaan: apa hubungan antara monoteisme dengan larangan membuat patung tuangan yang ia sebut Bilderverbot ${ }^{4}$ ? Apalagi landasan larangan ini sangat problematik dalam konteks Israel. Untuk itu, Mac Donald melakukan eksaminasi hubungan antara Bilderverbot dan kesatuan Yahweh dalam Deuteronomi; khususnya hubungan Bilderverbot yang berkembang luas di Israel. Nampaknya ada tiga klasifikasi yang dibuat Mac Donald bagi perkembangan aniconismee di Israel yang dicatat dalam Deuteronomi 4; pertama, aniconism merupakan hasil dari kepercayaan Israel terhadap natur Yahweh, seperti spiritualitas, invisibilitas, atau transendesi Allah. Monoteisme dan aniconisme merupakan karakteristik dari natur Yahweh. Kedua aniconisme hasil dari faktor-faktor sosial yang merupakan bagian integral dari natur Israel. Ketiga, aniconisme merupakan hasil dari natur patung/gambar itu sendiri.

Bagi Mac Donald, Deuteronomi 4 memiliki empat elemen yang saling berkaitan satu dengan lainnya. Kesinambungan ini terlihat dalam ayat 39-40

\footnotetext{
${ }^{4}$ Mac Donald menggunakan istilah Jerman Bilderverbot untuk mengkover beberapa larangan pembuatan patung atau gambaran yang ditemukan dalam seluruh Perjanjian Lama. Bagi Mac Donald, Bilderverbot memiliki jangkaun pengertian yang lebih luas dari istilah Ingris "the prohibition of images".
} 
dimana ketaatan berkaitan dengan pengakuan Yahweh sebagai Allah; Yahweh yang adalah Allah yang berdiam disurga dan di bawah bumi ${ }^{5}$, dan yang memberikan tanah kepada Israel. Hubungan ini terihat dalam forma dialektikal; tanah dan ketaatan sangat berhubungan erat. Sebaliknya, ketaatan bergantung saat masih berada di tanah perjanjian, sekaligus kehidupan Israel di tanah perjanjian bergantung pada ketaatannya. Hal ini nampaknya berlaku juga dalam peristiwa Keluaran yang menunjukkan pemilihan Yahweh atas Israel sekaligus menjadikan Yahweh sebagai Allah Israel. Hal ini menuntun pada kewajiban untuk menjaga perintahperintahNya dengan segenap hati. Sedangkan peristiwa Horeb yang menunjukkan Yahweh sebagai Allah di surga dan di bumi, membawa pada kewajiban untuk tidak membuat kehadiran Yahweh dalam bentuk yang tidak 'semestinya', Bilderverbot. Dia hanya hadir dalam ketaatan dan seruan yang selalu berkumandang kepadaNya. Bilderverbot merupakan bagian dari ketaatan sepenuhnya pada hukum; dan mungkin yang paling utama adalah pengakuan bahwa YAHWEH adalah Allah yang bertahta di surga dan dibumi, vice versa.

Kehadiran Yahweh yang digambarkan sebagai hadir di surga dan di bumi, secara khusus disadari berdasarkan ketaatan Israel terhadap firman Yahweh yang menjadi tema sentral dalam Deuteronomi 4. Akan tetapi, Mac Donald juga melihat kehadiran Yahweh sudah terlihat semenjak pasal 1-3 ketika Musa berdoa dan meminta penyertaan Yahweh penguasa surga dan bumi ketika mereka mulai masuk Kanaan. Pengakuan kuasa Yahweh dan 'kehadiranNya' mendapatkan pembenaran dalam tindakan Israel terhadap bangsa-bangsa sekitar Transjordan (24-25). Jadi, baik Ulangan 1-3 dan 4, kita menemukan tema yang identik mengenai 'kehadiran' Yahweh berdasarkan ketaatan Israel itu sendiri. Hal ini cocok dengan proklamasi Musa: untuk menguasai Kanaan sangat bergantung pada kehadiran Yahweh yang mana dapat terjadi apabila Israel taat terhadap perintah Yahweh. Bagi penulis, hubungan dialektik antara ketaatan dan penguasaan tanah sebenarnya tidak begitu jelas dalam Ulangan 1-3, akan tetapi, telah dikatahui bersama bahwa tidak mungkin ada penguasaan Kanaan tanpa ketaatan kepada Yahweh yang telah 'hadir' bersama umatnya, yang

\footnotetext{
${ }^{5}$ Konteks ini lebih dimaksudkan 'kehadiran' Allah dimanapun, dan bukan ekstensi 'kekuasaannya'.
} 
seringkali direpresentasikan dalam Bilderverbot dimana Israel bisa bertemu dan memujinya. Dalam cerita lembu tuangan, kehadiran (Bildevervot) Yahweh mendapat legitimasinya dalam dua tablet yang dibawa Musa dan harus ditaati, dilawankan patung lembu tuangan yang illegal.

Kehadiran Yahweh dijamin akan terus bersama Israel walaupun ada peristiwa Kades Barnea yang mengasumsikan jika Musa tidak bersama Israel, maka yahweh juga. Untuk itu, Musa memberikan jaminan bahwa Yahweh akan selalu hadir bersama Israel dalam beragam cara agar mereka tetap mengikuti segala ketatapanNya - mengingat ketaatan merupakan prasyarat kehadiran Yahweh bersama umatnya - Taurat, bahkan lebih dari yang lainnya sebagai jaminan Yahweh selalu bersama umatnya. Keputusan Yahweh untuk tidak bersama umatnya lebih dikarenakan Israel berjalan tidak dalam ketatapan Yahweh; terutama ketika mereka membuat patung tuangan/ berhala yang merupakan karakteristik bangsa-bangsa sekitarnya. Ide Bilderverbot mendapat pembenarannya karena Yahweh dinyatakan sebagai penguasa di surga sekaligus di 'bumi'. Ia hadir bersama Israel di Horeb, kemudian hadir bersama mereka melalui ketaatn pada firmanNya. Bilderverbot hanya dapat dideteksi melalui hubungan Yahweh dengan umatnya dan bukan dengan berhala lainnya.

Tujuan Awal dari buku ini tidak dimaksudkan untuk mempresentasikan doktrin mengenai Allah yang digambarkan dengan istilah 'monoteisme'. Pengakuan akan Yahweh adalah satu, unik, dan tidak ada yang lain di Israel, tidak bisa disebut sebagai 'monoteisme'. Ulangan 6:4 menjadi penting dalam pembahasan Mac Donald sebagai sumber produk monoteisme - sekaligus tidak mungkin menggambarkan doktrin tentang Allah dalam Deuteronomi. Walaupun dalam awal-awal bab pembahasan, ia menemukan bahwa ide monoteisme sangat beragam, bahkan ada yang berakar dalam rasionalisme; dalam arti pengertian rasionalisme yang dimiliki oleh Israel yang memiliki satu Allah melawan agama-agama penyembah berhala dan ateisme.

Monoteisme adalah kategori intelektual yang menunjukkan kepada klaim metafisik. Namun demikian, Deuteronomi tidak pernah mengenyampingkan keberadaan alah lain; sebaliknya penekanan lebih diarahkan pada pentingnya eksklusivisme Yahweh di Israel. Deueronomy bagi Mac Donald adalah sekumpulan teks yang mendorong Israel untuk 
mengasihi Yahweh yang adalah satu yang membawa mereka keluar dari Mesir dan masuk dalam panggilan ketaatan padaNya. Pengertian monoteisme ini memahami ada allah lain dalam bentuk beragama yang disebut allah palsu yang dapat menarik mereka keluar dari kasih Yahweh. Untuk itu mereka diingatkan bahwa pengakuan mereka akan allah yang satu berkaitan erat dengan pemilihan mereka, yang mana menjadi tema sentral dari Deuteronomi. Doktrin Deuteronomi mengenai pemilihan mengimplikasikan bangsa-bangsa sekitar Israel akan menerima pengetahuan tentang YAHWEH melalui Israel, tanpa ada semacam tanggung jawab misi Israel untuk menyatakan kepada mereka. Pesan Deuteronomi adalah supaya Israel memahami bahwa pemilihan mereka berkaitan erat dengan devosi dan ketaatan kepada hukum-hukum Yahweh.

Deuteronomi pada akhirnya bukanlah sekumpulan teks yang mencoba meyakinkan kita mengenai argumentasi hadirnya satu allah dan bukan banyak allah, melainkan berupaya mendorong Israel untuk memilih Yahweh sebagai satu-satunya Allah mereka yang hidup. Karya Mac Donald ini mengingatkan kita bahwa ada 'allah-allah' yang dapat menyeret kita menjauh dari Yahweh, oleh karena itu kita mesti bersikap monoteistik dengan tetap memberikan devosi kepada Dia. Monoteistik disini mengharuskan terus terjalinnya hubungan intim dengan Yahweh.

Buku ini pada akhirnya memiliki banyak hal penting yang dapat menjadi kontribusi dalam dunia tafsir Perjanjian Lama; diataranya adalah interpretasi atas istilah Shema oleh Mac Donald yang dihubungkan dengan keunikan serta kesatuan Yahweh dalam Deuteronomi 6, yang kemudian menempatkan Israel sebagai milik pusaka, merupakan bentuk pengakuan bahwa Israel merupakan satu-satunya umat pilihan Yahweh dan Yahweh menjadi satu-satunya Allah mereka. Selain itu, penolakan atas ide monoteisme modern yang ditempelkan kepada model beragama orang Israel kuno yang ditentang Mac Donald menjadi catatan penting untuk diperhatikan disebabkan Israel pada akhirnya tidak dapat dikatakan monoteis - dalam hal ini monoteis dalam terma modern.

Akan tetapi, pengakuan monoteis-etis yang dianut Mac Donald ini pada akhirnya bermasalah dalam konteks beragama orang Israel itu sendiri. Mac Donald dalam buku ini tidak menyinggung sama sekali keberagaman ilah lain yang hadir dalam konstelasi sistem agama Israel - yang seringkali 
mendapat tempat sejajar dengan Yahweh; sebut saja Asherah atau Ba'al. bahwa tradisi biblikal memiliki klaim hadirnya allah lain selain Yahweh; seperti terekam dalam sistem panteon El, bukan sesuatu yang bias dihindari. Pada masa awal jaman besi I, Israel tidak berbeda dengan masyarakat Kanaan pada umumnya: beberapa ilah yang disembah orang Israel saat itu merupakan tipikal ilah-ilah umum yang disembah masyarakat SyroPalestina. Secara Khusus, "Ba'al dan Ahserah merupakan allah-allah orang Israel" dan penolakan terhadap kultus meraka yang terjadi pada abad 8-6 SM, justru mendemonstrasikan bahwa kultus para dewa-dewi ini nyata dan menjadi ancaman bagi konsep monoteisme seperti yang digambarkan Mac Donal. Pertanyaan krusial seharusnya bukanlah "mengapa monarki menerima praktek-praktek ilah-ilah tersebut dan harus menerima kutukan dari nabi-nabi profetik?', tetapi, mengapa para nabi yang mengutuki praktek-praktek tersebut? Pertanyaan historis yang sebenarnya bukanlah seperti apa yang Yeremia teriakkan "mengapa umat ini berpaling dari-pada Tuhan"? Tapi mengapa para nabi yang berpaling dari Ba'al"?6 Faktanya, orang Israel seperti yang diucapkan Yeremia "anak-anak Israel ingat kepada altar-altar, asherim, pohon-pohon terbantin, dibukit-bukit...(Yer, 17:2), menunjukkan kesadaran umat itu bahwa baik Asherah maupun Yahweh merupakan bagian dari legasi Israel - persis seperti yang terlihat kehadiran mereka selama lebih dari 300 tahun di bait Allah Yerusalem saat dibersihkan dalam reformasi raja Yosia dalam 2 Raja-raja 23. Beberapa argumentasi ini nampaknya luput dalam perhatian Natan Mac Donald dalam buku ini.

${ }^{6}$ Mark S. Smith, The Early History of God: Yahweh and Other Deities in Ancient Israel, (Grand Rapids, MI: Eerdsmans, 2002), 189 